\title{
Mahrus
}

\section{IMPLEMENTASI METODE PEMBELAJARAN PENDIDIKAN KARAKTER ANAK USIA DINI DI PAUD PONDOK PESANTREN AL BAROKAH AJUNG JEMBER}

\author{
Mahrus \\ Dosen FTIK IAIN Jember \\ mabrusaditia@gmail.com
}

\begin{abstract}
The problems will be examined in this study are: (1) How understanding the basic concept of the character of early childhood education in boarding school PAUD AlBarokah, Ajung? (2) How is implementation of learning methods of early childhood character education in PAUD Al Barokah Boarding School? (3) How to faced constraints in the process of implementation of character education in PAUD Al Barokah boarding school, Ajung.? This Research to know (1) Understanding the basic concept of the character of early childhood education in boarding school PAUD Al-Barokah, Ajung (2) Implementation of learning methods of early childhood character education in PAUD Al Barokah Boarding School (3) Faced constraints in the process of implementation of character education in PAUD Al Barokah boarding school, Ajung. This research was exploratory, qualitative method using the method of data collection by using the observation method, interview and documentation. And analyzed using the descriptive method, preparation of requirement and the validity of the data. Based in the presentation and analysis of data in general it can be concluded that (1) understanding of the basic concepts of early childhood character education in PAUD Al Barokah boarding school are quite diverse, (2) Implementation of learning methods of early childhood character education by using several methods, such as using Conditioning methods, Example, story, field trip and demonstration, (3) As for the barriers are is the language, the number of teachers, APE and textbooks.
\end{abstract}

\section{Keywords: Learning Methods, Character Education, Early Childhood}

\section{Abstrak}

Permasalahan yang akan dikaji dalam penelitian ini adalah : (1)Bagaimana pemahaman konsep dasar pendidikan karakter anak usia dini di PAUD Pondok Pesantren Al Barokah Kecamatan Ajung, (2) Bagaimana inplementasi metode pembelajaran pendidikan karakter anak usia dini di PAUD Pondok Pesantren Al Barokah Kecamatan Ajung, (3) Bagaimana kendala-kendala yang dihadapi dalam menginplementasi metode pembelajaran pendidikan karakter di PAUD Pondok Pesantren Al 
Barokah Kecamatan Ajung. Adapun penelitian ini menggunakan metode kualitatif eksploratif, metode pengumpulan data dengan menggunakan metode abservasi, interview, dan dokumentasi. Dan dianalisis dengan menggunakan metode diskriptif, penyususnan katagori dan validitas data. Berdasarkan penyajian dan analisis data secara umum dapat disimpulkan bahwa (1) Pemahaman Konsep Dasar Pendidikan Karakter Anak Usia Dini di PAUD Pondok Pesantren Al Barokah Kecamatan Ajung cukup beragam,(2) Implementasi Metode Pembelajaran Pendidikan Karakter Anak Usia Dini dengan menggunakan beberapa metode, diantaranya adalah dengan menggunakan Metode Pembiasaan, Keteladanan, Kisah, Karyawisata dan demontrasi, (3) Adapun kendalanya adalah bahasa, jumlah tenaga pengajar, APE dan buku pelajaran.

\section{Kata Kunci : Metode Pembelajaran, Pendidikan Karakter, Anak Usia Dini}

\section{Pendahuluan}

Pendidikan anak usia dini adalah suatu upaya pembinaan yang ditujukan kepada anak sejak lahir sampai dengan usia enam tahun yang dilakukan melalui pemberian rangsangan pendidikan untuk membantu pertumbuhan dan perkembangan jasmani dan rohani agar anak memiliki kesiapan dalam memasuki pendidikan lebih lanjut. ${ }^{1}$

${ }^{1}$ Dirjen Pendidikan Islam Depatemen Agama RI,UUSPN Nomor 20 tahun
Pendidikan anak usia dini dapat memberikan pengaruh yang membekas sehingga melandasi proses pendidikan dan perkembangan anak selanjutnya. Pandangan ini didasarkan pada alasan keagamaan, pandangan para ahli maupun temuan-temuan ilmiah.

Agama memandang, anak sebagai aset yang sangat berharga untuk investasi masa depan baik

2003 tentang sistem pendidikan Nasional, tahun 2006, 6. 


\section{Mahrus}

duniawi maupun ukhrawi. Aset ini diinvestasikan semaksimal mungkin agar kelak si anak menjadi manusia yang sempurna (insan kamil). Kegagalan dalam menginvestasikan aset (mendidik anak) bisa mendatangkan petaka (fitnah) bagi kedua orang tua maupun pendidik, di dunia maupun akhirat.

Pendidikan anak usia dini adalah pondasi awal untuk meletakkan nilai-nilai yang baik. Dalam proses pembelajarannya perlu adanya metode yang tepat, sehingga akan menghasilkan produk yang sesuai dengan tujuan. Terlebih dalam menanamkan nilai-nilai khususnya nilai-nilai akhlak atau sering disebut dengan pendidikan karakter.

Pendidikan karakter muncul ke permukaan ketika terjadi degradasi moral yang melanda bangsa Indonesia. Namun hakekatnya pendidikan karakter ini telah muncul sejak dulu. Akan tetapi trenya baru muncul pada saat ini. ${ }^{2}$ Untuk dapat mengetahui makna yang sesungguhnya mengenai pendidikan karakter, tentu dibutuhkan penjelasan dan pembahasan yang mendalam. Tidak hanya sebatas pada pengertian, tetapi pada sampai tujuan, manfaat dan prinsipprinsip pelaksanaannya $^{3}$ Berangkat dari kenyataan diatas, maka pendidikan karakter anak usia dini di lembaga pendidikan menjadi sangat penting untuk diteliti.

Berangkat dari latar belakang di atas, maka permasalahan yang akan dikaji dalam penelitian ini mengenai masalah : Pemahaman konsep dasar pendidikan karakter anak usia, inplementasi metode pembelajaran pendidikan karakter anak usia dini dan kendala-kendala yang dihadapi dalam menginplementasikan metode

\footnotetext{
${ }^{2}$ Muhammad Fadlillah,Pendidikan Karakter Anak Usia Dini, (Jogjakarta:ArRuzz Media, 2013),16.

3Ibid. Hal.15
} 
pembelajaran pendidikan karakter pada anak usia dini.

\section{Tinjauan Pustaka}

Pendidikan karakter bersal dari dua kata yaitu pendidikan dan karakter yang memiliki makna yang berbeda. Pendidikan lebih merujuk pada kata kerja sedangkan karakter lebih kepada kata sifat. Dapat diartikan melalui proses pendidikanberkarakter berarti akan menghasilkan sebuah karakter yang baik.

Pendidikan sendiri merupakan terjemahan dari education, yang kata dasarnya educate dan bahasa latinya educo. Educo berarti mengembangkan dari dalam; mendidik; melaksanakan hukum kegunaan. ${ }^{4}$ Pendidikan menurut $\mathrm{Ki}$ Hajar Dewantara adalah daya upaya untuk

${ }^{4}$ Muhammad Fadlillah,Pendidikan Karakter Anak Usia Dini, (Jogjakarta:ArRuzz Media, 2013),16. memajukan budi pekerti, pikiran, serta jasmani agar dapat memajukan kehidupan yang selaras dengan alam dan masyarakatnya. ${ }^{5}$

Menurut T. Ramli, pendidikan karakter memiliki esensi dan makna yang sama dengan pendidikan moral dan pendidikan akhlak. ${ }^{6}$ Menurut Doni A. Koesoema, pendidikan karakter terdiri dari beberapa unsur, diantaranya penanaman karakter dengan pemahaman pada peserta didik tentang struktur nilai dan keteladanan yang diberikan pengajar dan lingkungan. ${ }^{7}$.

Kemendiknas menjelaskan bahwa nilai-nilai karakter yang

${ }^{5}$ Hartono, Pengertian Pendidikan, http:// fatamorghana.wordpress. com, diakses pada 20 Mei 2014.

${ }^{6}$ Akhmad Sudrajat, Konsep Pendidikan Karak-

ter,http://akhmadsudrajat.wordpress. com, diakses pada 20 Mei 2014

${ }^{7}$ Doni Koesoema A., Pendidikan Karakter, (Jakarta: Grasindo, 2007),9. 


\section{Mahrus}

dikembangkan dalam dunia pendidikan didasarkan pada 4 sumber, yaitu ; agama, Pancasila, budaya bangsa dan tujuan pendidikan nasional itu sendiri. Dari keempat sumber tersebut merumuskan 18 nilai-nilai karakter umum yaitu : Religius, jujur, toleransi, disiplin, kerja keras, kreatif, mandiri, demokratis, rasa ingin tahu, semangat kebangsaan, cinta tanah air, menghargai prestasi, bersahabat/komunikatif, cinta damai, gemar membaca, peduli lingkungan, peduli sosial, tanggung jawab. ${ }^{8}$

Karakter secara kebahasaan ialah sifat-sifat kejiwaan, akhlak atau budi pekerti yang membedakan seseorang dari yang lain, tabiat atau watak. ${ }^{9}$ Pendidikan karakter adalah suatu sistem penanaman nilai-nilai karakter

${ }^{8}$ Badan Penelitian dan Pengembangan Puskur Kemendiknas, Bahan Pelatihan Pengembangan Pendidikan Budaya dan Karakter Bangsa, Jakarta : Kemendiknas,2010),11.

${ }^{9}$ Nashir Haedar, Pendidikan Karakter Berbasis Agama \& Budaya, (Yogyakarta: Multi Presindo,2013),10. kepada warga sekolah yang meliputi komponen pengetahuan, kesadaran atau kemauan, dan tindakan untuk melaksanakan nilai-nilai tersebut. Dalam Pendidikan karakter di sekolah, semua komponen (pemangku pendidikan) harus dilibatkan termasuk komponen-komponen pendidikan itu sendiri, seperti kurikulum, proses pembelajaran dan penilaian, penanganan atau pengelolaan mata pelajaran, pengelolaan sekolah, pelaksanaan aktivitas atau kegiatan kulikuler, pemberdayaan sarana prasrana, pembiayaan dan etos kerja seluruh warga sekolah/lingkungan. Di samping itu, pendidikan karakter dimaknai sebagai suatu prilaku warga sekolah yang dalam penyelenggaraan pendidikan harus berkarakter. $^{10}$

Pendidikan merupakan upaya untuk mengembangkan ranah kognitif, afektif dan

\footnotetext{
${ }^{10}$ Aqib Zainal,Panduan \& Aplikasi Pendidikan Karakter,(Bandung: Yrama Widya,2012), 3.
} 
psikomotorik. Muara ranah kognitif adalah tumbuh dan berkembangnya kecerdasan dan kemampuan intelektual akademik, ranah afektif berujung pada terbentuknya karakter kepribadian, dan ranah psikomotorik akan berujung pada keterampilan vokasional dan perilaku. Pembentukan karakter adalah upaya membantu perkembangan jiwa anak baik lahir maupun batin, dari sifat kodratinya menuju ke arah peradaban masyarakat dan bangsa secara umum. Pendidikan pembentukan karakter merupakan upaya untuk menumbuhkan dan mengembangkan nilai-nilai yang baik atau positif pada diri anak sesuai dengan etika moral yang berlaku. Anak tidak hanya tahu apa yang seharusnya dilakukan tetapi juga memahami mengapa hal tersebut dilakukan, sehingga anak akan berprilaku seperti yang diharapkan. Pendidikan karakter bersifat terus menerus dan berkelanjutan, yaitu mulai dari pendidikan anak usia dini hingga perguruan tinggi, agar terinternalisasi dengan baik dalam diri anak. ${ }^{11}$

Maka dapat disimpulkan bahwa makna pendidikan karakter adalah suatu sistem penerapan nilai-nilai moral pada peserta didik melalui ilmu pengetahuan, kesadaran atau kemauan, dan implementasi nilai-nilai tersebut, baik terhadap diri sendiri, sesama, lingkungan, bangsa dan negara maupun Tuhan Yang Maha Esa, kebangsaan sehingga menjadi manusia yang memiliki akblaqul karimah.

Semua usaha yang dilakukan tentunya memiliki tujuan yang

\footnotetext{
${ }^{11}$ Damayanti Deni, Panduan Implementasi Pendidikan Karakter Di Sekolah,(Yogyakarta:Araska, 2014),10.
} 


\section{Mahrus}

dicapai, begitu juga pendidikan karakter juga ada tujuan yang bersifat intern dan ekstern. Secara umum tujuan pendidikan adalah agar supaya manusia agar lebih baik, dan mampu mengembangkan kemampuanya.

Dalam UU No.20 tahun 2003 tentang Sistem Pendidikan disebutkan bahwa tujuan pendidikan ialah untuk berkembangnya potensi peserta didik agar menjadi manusia yang beriman dan bertakwa kepada Tuhan Yang Maha Esa, berakhlak mulia, sehat, berilmu, cakap, kreatif, mandiri dan menjadi warga negara yang demokratis serta bertanggung jawab. ${ }^{12}$

Pendidikan pada dasarnya merupakan upaya pembudayaan dan pemberdayaan untuk menumbuh kembangkan potensi dan kepribadian peserta didik sehingga mereka menjadi pribadi

\footnotetext{
${ }^{12}$ Direktorat Jendral Pendidikan Islam Departemen Agama RI, Undang-Undang Republik Indonesia Nomor 20 Tabun 2003 Tentang Sistem Pendidikan Nasional,9.
}

yang cerdas, berakhlak mulia, dan memiliki kemampuan dan keterampilan yang berguna bagi dirinya sendiri, masyarakat, bangsa dan negara. Pendidikan ingin mengembangkan potensi peserta didik secara utuh seimbang dan berkesinambungan, tidak hanya dimensi intelektual, tetapi juga dimensi spiritual, karakter, kinestik, dan sosial serta keterampilan yang diperlukan sebagai warga masyarakat dan warga negara. ${ }^{13}$

Berkaitan dengan pendidikan karakter, tujuan pendidikan yang telah ditetapkan pemerintah tersebut wajib ditaati dan diikuti. Dengan kata lain, bahwa tujuan pendidikan berkarakter tentu tidak boleh menyimpang dengan tujuan pendidikan yang sudah dirumuskan.

a. Implementasi Pembelajaran Pendidikan Karakter

\footnotetext{
${ }^{13}$ Nashir Haedar, Pendidikan Karakter Berbasis Agama \& Budaya, (Yogyakarta: Multi Presindo,2013),14.
} 
Vol. 13, No. 2, Oktober 2020

p-ISSN:2086 -0749

e-ISSN:2654-4784

Implementasi pendidikan karakter harus sejalan dengan orientasi pendidikan. Pola pembelajarannya dilakukan dengan cara menanamkan nilai-nilai moral tertentu dalam diri anak yang bermanfaat bagi perkembangan pribadinya sebagai makhluk individual sekaligus sosial. ${ }^{14}$. Implementasi pendidikan karakter melalui orientasi pembelajaran di sekolah lebih ditekankan pada keteladanan dalam nilai pada kehidupan nyata, baik di sekolah maupun di wilayah publik. ${ }^{15}$.

Noor Rochman Hadjam, SU. menjelaskan mendidikan karakter tidak hanya mengenalkan nilai-nilai secara kognitif tetapi juga melalui penghayatan secara afektif dan mengamalkan nilai-

${ }^{14}$ Doni A. Koesoema, Pendidikan Karakter, (Jakarta: Grasindo, 2007).

15 Acep Hermawan, Implementasi Pendidikan Karakter, http://www.klik-galamedia.com, diakses pada 20 Mei 2014. nilai tersebut secara nyata dalam kehidupan sehari-hari. Kegiatan siswa seperti pramuka, upacara bendera, palang merah remaja, teater, praktek kerja lapangan, menjadi relawan bencana alam, atau pertandingan olahraga dan seni adalah cara-cara efektif menanamkan nilai-nilai karakter yang baik pada siswa. Ia menekankan pendidikan berbasis karakter bukan merupakan mata pelajaran tersendiri melainkan dampak pengiring yang diharapkan tercapai. ${ }^{16}$.Sementara itu $\mathrm{Ke}$ mendiknas menyebutkan beberapa prinsip pengembangan pendidikan karakter dan budaya bangsa di sekolah, yaitu: (1). Keberlanjutan; yaitu bahwa proses pengembangan nilai-nilai karakter dan budaya bangsa dimualai dari awal

\footnotetext{
${ }^{16}$ Lena, Implementasi Pendidikan Karakter Dalam Dunia Pendidikan,http://www.uny.ac.id, diakses pada 20 Mei 2014.
} 


\section{Mahrus}

peserta didik masuk hingga selesai dari satuan pendidikan. (2). Melalui semua mata pelajaran, pengembangan diri dan budaya sekolah.(3).Nilai-nilai tidak diajarkan tapi dikembangkan; yaitu bahwa nilai-nilai karakter bukan merupakan pokok bahasan yang harus diajarkan, sebaliknya mata pelajaran dijadikan sebagai bahan atau media mengembangkan nilainilai karakter. (4). Proses pendidikan karakter dilakukan oleh peserta didik secara aktif dan menyenangkan. ${ }^{17}$

b. Metode Pembelajaran

Pendidikan Karakter Nilai

Keagamaan (Akhlak)

Menurut T. Ramli, pendidikan karakter memiliki esensi dan makna yang sama dengan pendidikan moral dan pendidikan akhlak. ${ }^{18}$ Menurut Doni A.

\footnotetext{
${ }^{17}$ Badan Penelitian dan Pengembangan Puskur Kemendiknas, Baban Pelatihan Pengembangan Pendidikan Budaya dan Karakter Bangsa, (Jakarta : Kemendiknas, 2010), 25.

18 Akhmad Sudrajat, Konsep Pendidikan Karak-
}

Koesoema, pendidikan karakter terdiri dari beberapa unsur, diantaranya penanaman karakter dengan pemahaman pada peserta didik tentang struktur nilai dan keteladanan yang diberikan pengajar dan lingkungan. ${ }^{19}$.

Metode Pembelajaran Karakter Pada Anak Usia Dini

\section{Metode Pembiasaan}

Secara etimologi, pembiasaan berarasal dari kata "biasa". Dalam Kamus Besar Bahasa Indonesia, "biasa" adalah lazim atau umum; seperti sedia kala; sudah merupakan hal yang tidak dipisahkan dari kehidupan sehari-hari. Dengan adanya prefiks "pe" dan sufiks "an" menunjukkan arti proses sehingga kebiasaan dapat diartikan dengan proses membuat sesuatu/seseorang menjadi biasa. Dalam kaitannya dengan metode pembelajaran dalam pendidikan ter, http://akhmadsudrajat.wordpress. com, diakses pada 20 Mei 2014

${ }^{19}$ Doni Koesoema A., Pendidikan Karakter, (Jakarta: Grasindo, 2007),9. 
Vol. 13, No. 2, Oktober 2020

p-ISSN:2086 -0749

e-ISSN:2654-4784

Islam, dapat dikatakan bahwa pembiasaan adalah sebuah cara yang dapat dilakukan untuk membiasakan anak didik berfikir, bersikap dan bertindak sesuai dengan tuntutan ajaran agama Islam. ${ }^{20}$ Pembiasaan dinilai sangat efektif jika penerapannya dilakukan pada tahap awal atau pada tahap peserta didik yang berusia dini. Ketika anak masih kecil selalu dibiasakan untuk senantiasa melakukan ajaran agama, maka anak tersebut akan terbiasa melaksanakannya. Tanpa latihan dan pengalaman yang dibiasakan, maka akan sulit bagi seseorang anak untuk melaksanakan ajaran agama. ${ }^{21} \mathrm{Al}$ Qur'an sebagai sumber ajaran Islam memuat prinsip-prinsip umum pemakaian metode pembiasaan dalam proses

${ }^{20}$ Armai Arief, Pengantar Ilmu,110.

${ }^{21}$ Muhammad Azmi, Pembinaan Akblak. Anak Usia Pra Sekolah, 35. pendidikan. Dalam merubah perilaku negatif misalnya, al Qur'an memakai pendekatan pembiasaan secara berangsurangsur. Kasus pengharaman khamr misalnya.

\section{Metode Keteladanan}

Dalam Kamus Besar Bahasa Indonesia disebutkan bahwa "keteladanan" dasar katanya "teladan" yaitu perbuatan atau barang yang patut ditiru dan dicontoh. Oleh karena itu "keteladanan" adalah hal-hal yang dapat ditiru dan dicontoh. Dalam bahasa Arab keteladanan diungkapkan dengan kata "uswah" dan "qudwah", yang berarti suatu keadaan ketika seseorang manusia mengikuti manusia lain, apakah dalam kebaikan, kejelekan, kejahatan atau kemurtadan. Dengan demikian keteladanan adalah hal-hal yang dapat ditiru atau dicontoh oleh seseorang dari 


\section{Mahrus}

orang lain. Namun keteladanan yang dimaksud disini adalah keteladanan yang dapat dijadikan sebagai pendidikan Islam, yakni keteladanan yang baik. Sebagai pendidikan yang bersumber pada al Qur'an dan Sunnah Rasulullah, metode keteladanan tentunya didasarkan pada sumber tersebut. Dalam al Qur'an "keteladanan" diistilahkan dengan kata uswah.

\section{Metode Kisah}

Metode kisah mengandung arti suatu cara dalam menyampaikan materi pelajaran dengan menuturkan secara kronologis tentang bagaimana terjadinya sesuatu hal baik yang sebenarnya terjadi ataupun hanya rekaan. Dalam mengaplikasikan metode ini pada Proses Belajar Mengajar (PBM), metode kisah merupakan salah satu metode pendidikan yang masyhur dan terbaik. Sebab itu mampu menyentuh jiwa jika didasari ketulusan hati yang mendalam. Disamping itu metode kisah memiliki peranan penting dalam memperoleh ingatan anak dan kesadaran berfikir.

\section{Metode Karya Wisata}

Menurut H.Zuhairini dkk, metode karya wisata adalah suatu metode pengajaran yang dilaksanakan dengan jalan mengajak anak keluar kelas untuk dapat memperlihatkan hal-hal atau peristiwa yang ada hubungannya dengan pelajaran. Tim Diktatik Metodik Kurikulum menjelaskan, bahwa metode Karya Wisata adalah suatu metode mengajar dimana siswa dan guru pergi meninggalkan sekolah menuju ke suatu tempat untuk menyelidiki atau mempelajari hal tertentu. Dari beberapa pengertian tersebut di atas terlihat bahwa metode ini merupakan sebuah alternatif yang diperuntukkan bagi siswa agar mendapatkan/memperoleh pengalaman belajar yang tidak diperolehnya secara langsung di dalam kelas. Metode ini sangat baik dilakukan sebagai selingan out 
Vol. 13, No. 2, Oktober 2020

p-ISSN:2086 -0749

e-ISSN:2654-4784

door study sebab para siswa dapat diajak langsung ke alam yang sebenarnya.

\section{Metode Demonstrasi}

Yang dimaksud dengan metode demonstrasi adalah metode mengajar dengan menggunakan peragaan untuk memperjelas suatu pengertian atau untuk memperlihatkan bagaimana berjalannya suatu proses pembentukan tertentu kepada Peserta didik.

\section{Metodologi Penelitian}

Penelitian ini menggunakan pendekatan kualitatif, sehingga data yang dipaparkan dalam penelitian ini tidak berupa angkaangka, tetapi berupa uraian katakata. Sebagaimana lazimnya penelitian kualitatif, penelitian ini tidak dimaksudkan untuk menguji hipotesis yang telah dirumuskan, tetapi lebih berorientasi pada pengembangan dan pengetahuan baru yang diperoleh melalui pengamatan, wawancara, dan studi dokumentasi yang berkaitan langsung dengan pokok permasalahan. Pendekatan yang bersifat fenomenologis juga digunakan dalam penelitian ini. Dalam pendekatan fenomenologis peneliti berusaha memahami makna peristiwa serta interaksi pada orangorang dalam situasi tertentu. Pendekatan ini menghendaki adanya sejumlah asumsi yang berlainan dengan cara yang digunakan untuk mendekati perilaku orang dengan maksud menemukan fakta atau penyebab.

Penelitian ini dilaksanakan di PAUD Pondok Pesantren Al Barokah Desa Ajung Kecamatan Ajung Kabupaten Jember. Peneliti memilih lokasi ini karena di Pondok Pesantren Al Barokah ini semua biaya dan seragam di- 


\section{Mahrus}

tanggung oleh yayasan atau dengan kata lain gratis. Meskipun demikian para santri dan siswa di sini berprestasi.

Teknik pengumpulan data menggunakan observasi, wawancara, dan documentasi. Observasi dilakukan dengan cara mengamati secara langsung gejalagejala yang terjadi berkaitan dengan masalah penelitian. Observasi yang digunakan di sini adalah observasi nonpartisipan, maksudnya di sini peneliti hanya melakukan satu fungsi, yaitu mengadakan pengamatan. ${ }^{22}$ Selain mengunakan teknik observasi, pengumpulan data dalam penelitian ini juga dilakukan dengan menggunakan teknik wawancara mendalam. Secara teknis, wawancara mendalam ini dilakukan dengan mengkombinsikan dua jenis wawancara yakni wawancara terstruktur dan wawancara tidak terstruktur. Wa-

\footnotetext{
${ }^{22}$ Moleong, Metode Penelitian Kualitatif, edisi revisi (Bandung : PT Remaja Rosdakarya, 2007),126.
}

wancara terstruktur dilakukan dengan menggunakan pedoman wawancara. Sedangkan wawancara tak terstruktur dilakukan dengan bebas tanpa terikat dengan pedoman wawancara. Wawancara model yang kedua dikemas di dalam model percakapan santai tetapi tetap mengacu kepada masalahmasalah yang berkaitan dengan penelitian. Sementara itu, metode dokumentasi digunakan untuk memperoleh data-data yang berupa dokumen-dokumen berkaitan dengan data data yang dibutuhkan.

Setelah data-data dikumpulkan, kemudian dilakukan reduksi data, klasifikasi data, display data dan memberikan penafsiran, interprestasi, dan penyimpulan. ${ }^{23}$ Data-data yang dikumpulkan dalam penelitian ini adalah data-data verbal yang harus ditangkap maknanya. Data-data ini kemudian diinventarisasi dengan diketik da-

\footnotetext{
${ }^{23}$ Kailan M.S., Metode Penelitian Kualitatif Bidang Pendekatan Filsafat, (Yogyakarta : Paradigma, 2005), 68.
} 
Vol. 13, No. 2, Oktober 2020

p-ISSN:2086 -0749

e-ISSN:2654-4784

lam bentuk uraian dan laporan yang terinci. Laporan-laporan itu kemudian direduksi, artinya dirangkum, dipilih hal-hal yang pokok, difokuskan pada hal-hal yang penting, dicari substansi serta pola-polanya. Data yang berupa uraian verbal itu diseleksi dan direduksi esensi maknanya sesuai permasalahan yang diteliti.

Hasil reduksi data mengarahkan peneliti untuk mengetahui peta esensial yang menyangkut kandungan makna yang ada di dalam data. Kemudian tahap berikutnya melakukan klasifikasi data, yaitu mengelompokkan data-data berdasarkan ciri khas masing-masing berdasarkan objek penelitian. Dalam proses klasifikasi ini data-data yang kurang relevan serta data-data yang tidak dimiliki hubungan dengan tujuan penelitian akan disisihkan.
Tahap berikutnya peneliti membuat display data, yaitu mengorganisasikan data-data tersebut dalam suatu peta yang sesuai dengan objek dan tujuan penelitian. Display data dapat juga dengan membuat semacam networks atau skematisasi yang berkaitan dengan konteks data tersebut. Dengan membuat display data maka masalah makna data yang terdiri atas berbagai macam konteks dapat terkuasai petanya.

Proses analisis dan interpretasi data dimulai sejak pengumpulan data, kemudian analisis dan sekaligus juga melakukan penafsiran-penafsiran dan diinterpretasi sesuai dengan konteks data yang telah dikumpulkan. Proses penafsiran dan interpretasi ini dalam rangka mengungkap makna yang terkandung dalam data-data verbal tersebut. Tahap berikutnya 


\section{Mahrus}

kemudian menyimpulkan data yang telah terkumpul,secara bertahap, pertama diberikan suatu kesimpulan, tahap kedua juga dilakukan suatu kesimpulan, demikian pula tahap ketiga dan akhirnya secara keseluruhan disimpulkan dengan menggunakan hukum-hukum logika, yaitu induktif aposteriori. ${ }^{24}$

\section{Temuan Hasil Penelitian}

\section{dan Pembahasan}

Pemahaman Guru Tentang Konsep Dasar Pendidikan Karakter Anak Usia Dini Pendidikan anak usia dini adalah suatu upaya pembinaan yang ditujukan kepada anak sejak lahir sampai dengan usia enam tahun yang dilakukan melalui pemberian rangsangan pendidikan untuk membantu pertumbuhan dan perkembangan jasmani dan rohani agar anak memiliki kesipan dalam memasuki pendidikan lebih lanjut.pendidikan karakter adalah suatu sistem pen- erapan nilai-nilai moral pada peserta didik melalui ilmu pengetahuan, kesadaran atau kemauan, dan implementasi nilai-nilai tersebut, baik terhadap diri sendiri, sesama, lingkungan, bangsa dan negara maupun Tuhan Yang Maha Esa, kebangsaan sehingga menjadi manusia yang memiliki akhlaqul karimah. bersifat terus menerus dan berkelanjutan, yaitu mulai dari pendidikan anak usia dini hingga perguruan tinggi, agar terinternalisasi dengan baik dalam diri anak, dan pengamalan nyata dalam kehidupan sehari-hari di masyarakat.

Setelah dipaparkan data dokumentasi tentang PAUD Al Barokah An-Nur maka berikut ini akan dipaparkan data hasil penelusuran melalui wawancara yang akan mendiskripsikan pemahaman guru tentang konsep dasar pendidikan karakter anak usia dini. Dari hasil wawancara ternyata terdapat berbagai macam pemaham-

\footnotetext{
${ }^{24}$ Ibid., hal. 71
} 
Vol. 13, No. 2, Oktober 2020

p-ISSN:2086 -0749

e-ISSN:2654-4784

an guru tentang konsep dasar pendidikan karakter anak usia dini.

Menurut Ibu Junaidah bahwa "sebenarnya pendidikan karakter itu sudah ada dan sering kita lakukan dalam proses pembelajaran di PAUD, selanjutnya dia mengatakan bahwa kita sering memberikan contoh kepada peserta didik PAUD misalnya : sebelum makan kita membaca do'a itu berarti kita menanamkan nilai-nilai moral atau akhlak kepada Allah, sebagai ungkapan syukur kepadaNya". 25

Menurut penuturan Ibu farah bahwa yang dimaksud dengan pendidikan karakter adalah pendidikan akhlak. Untuk mengimplementasikan pendidikan karakter perlu adanya pembiasaan misalnya dengan ibadah shalat 2014 berjamaah dan bersalaman ketika bertemu dengan ibu guru. ${ }^{26}$

Menurut Ibu Rohmah bahwa karakter adalah watak atau tabiat dan cara berprilaku dalam kehidupan sehari-hari, misalnya anak anak yang dibiasakan dengan berdo'a sebelum makan, sebelum belajar dan lain-lain serta melakukan cuci tangan sebelum dan sesudah makan.27

Metode Pembelajaran Pendidikan Karakter Anak Usia Dini

Dalam proses pembelajaran tentunya tidak dapat dilepaskan dari materi, metode dan strategi pembelajaran, penggunaan media dan evaluasi pembelajaran, baik yang bersifat kokorikuler maupun ekstra kurikuler. Berdasarkan hasil interview di atas dapat dipaparkan bahwa untuk menginplementasi-

\footnotetext{
26 Hasil Wawancara tanggal 15 Agustus 2014

27 Hasil Wawancara tanggal 15 September 2014
} 


\section{Mahrus}

kan pendidikan karakter dapat dilakukan dengan menggunakan beberapa metode, diantaranya adalah dengan menggunakan Metode Pembiasaan, Keteladanan, Kisah, Karyawisata dan demontrasi.

\section{Sebagaimana} yang

dikemukakan oleh ibu Junaidah: Untuk menanamkan sikap disiplin pada anak, sebaiknya guru juga harus disiplin, sebagaimana yang saya lakukan tiap pagi, saya sebagai kepala sekolah datang lebih awal pada setiap harinya, untuk menyambut kedatangan para peserta didik. $^{28}$ Kendala Dalam Mengimplementasikan Pendidikan Karakter Anak Usia Dini.

Berdasarkan hasil wawancara tersebut di atas maka dapat dikemukakan bahwa dalam mengimplementasikan pendidikan karakter anak usia dini di PAUD Al Barokah An-Nur, tidak terlepas dari berbagai macam kendala, yai- tu sarana dan prasarana yang masih kurang menjadi kendala dalam mengimplementasikan pendidikan karakter. Seperti keterseidaan alat untuk mengevaluasi pelaksanaan pendidikan karakter bagi siswa. Dalam mengimplementasikan pendidikan karakter memerlukan dukungan dari berbagai pihak, tidak hanya dari guru dan pihak sekolah tetapi juga keluarga serta lingkungan masyarakat sekitar siswa agar terjadi lingkungan komunitas yang sinergi dan menghasilkan tatanan masyarakat yang berkarakter. Dan kendala yang lain adalah masalah bahasa, karena mayoritas dari siswa berbahasa Madura, campur tangan ibu atau wali murid yang ikut campur di dalam kelas, jumlah tenaga pengajar juga menjadi kendala dalam pelaksanaan metode pembelajaran Pendidikan karakter. Dan yang tak kalah pentingnya adalah APE dan buku dan

\footnotetext{
${ }^{28}$ Hasil Wawancara tanggal 16 September 2014
} 
juga pengawasan terhadap siswasiswi. ${ }^{29}$.

\section{Simpulan}

Berdasarkan penyajian dan analisis data secara umum dapat disimpulkan bahwa Pemahaman Konsep Dasar Pendidikan Karakter Anak Usia Dini di PAUD Pondok Pesantren Al Barokah Kecamatan Ajung cukup beragam, Implementasi Metode Pembelajaran Pendidikan Karakter Anak Usia Dini dengan menggunakan beberapa metode, diantaranya adalah dengan menggunakan Metode Pembiasaan, Keteladanan, Kisah, Karyawisata dan demontrasi, Kendala. Yang dihadapi dalam implementasi pembelelajaran yaitu bahasa, jumlah tenaga pengajar, APE dan buku pelajaran.

\footnotetext{
${ }^{29}$ Hasil Wawancara tanggal 20 Sptember 2014
}

Berdasarkan paparan dan kesimpulan yang telah diuraikan di atas perlu kiranya diberikan beberapa saran sebagai berikut: Perlu adanya pemahaman secara komprehensip tentang pendidikan karakter, sehingga lebih mudah dalam menggunakan metode pembelajaran pendidikan karakter Anak Usia Dini, dengan menggunakan metode pembiasaan, keteladanan, kisah, Karyawisata dan demontrasi. Perlu adanya fasilitas yang memadai dan tenaga pengajar yang cukup.sehingga kendala-kendala dalam proses pembelajaran pendidikan karakter dapat diminimalisir.

\section{Daftar Pustaka}

Dirjen Pendidikan Islam Depatemen Agama RI,UUSPN Nomor 20 tahun 2003 tentang sistem pendidikan $\mathrm{Na}$ sional, tahun 2006 . 


\section{Mahrus}

Muhammad Fadlillah,Pendidikan Karakter Anak Usia Dini, (Jogjakarta:Ar-Ruzz Media, 2013)

Hartono, Pengertian Pendidikan, http:// fatamorghana.w ordpress.com, diakses pada 20 Mei 2014.

Doni Koesoema A., Pendidikan Karakter, (Jakarta: Grasindo, 2007).

Muhammad Azmi, Pembinaan Akblak Anak Usia Pra Sekolah

Moleong, Metode Penelitian Kualitatif, edisi revisi (Bandung : PT Remaja Rosdakarya, 2007).

Kailan M.S., Metode Penelitian Kualitatif Bidang Pendekatan Filsafat, (Yogyakarta : Paradigma, 2005). 